\title{
Ekonomia społeczna a wykluczenie społeczne - uwagi wstępne
}

Konieczność przeciwdziałania wykluczeniu społecznemu nie jest obecnie praktycznie podważana ani przez znaczących autorów, ani przez organy państwowe, ani też przez znaczące partie i ugrupowania polityczne. Gdyby poszukiwać współcześnie tematów społecznych powszechnie akceptowanych mimo wysokiego stopnia polaryzacji społecznej i politycznej, to przeciwdziałanie wykluczeniu społecznemu i ekonomia społeczna jako ważny instrument tego przeciwdziałania byłaby rzadkim wyjątkiem takich tematów, może z wyjątkiem ugrupowań zupełnie skrajnych. Równocześnie mimo zaangażowanych działań naukowych i społecznych, których świadectwem jest niniejszy numer czasopisma, ekonomia społeczna w Polsce wciąż nie może przebić swoistego „szklanego sufitu”, nie może wyjść ze sfery pozytywnie ocenianych a nawet podziwianych innowacji społecznych i eksperymentu administracyjnego.

W świetle tekstów opublikowanych w niniejszym zbiorze palącym wyzwaniem współczesności wydaje się więc nie tyle dalsze przekonywanie do zasad i form ekonomii społecznej, ile swoista redefinicja problemu: przeniesienie ciężaru na kwestie upowszechnienia ekonomii społecznej, umieszczenia jej w głównym nurcie działań, zwłaszcza organów samorządu terytorialnego. Jak wskazuje się w literaturze, powszechna znajomość pojęcia problemu i podstawowych form pomocy społecznej kontrastuje ze słabą rozpoznawalnością pojęcia i form ekonomii społecznej. Niezbędna wydaje się więc stopniowa zmiana paradygmatu, zwłaszcza, że ekonomia społeczna jest najbardziej trwałą i efektywną formą współczesnej pomocy społecznej sensu largo. Ponadto obecna sytuacja następująca po pandemii w nieoczekiwany sposób przyczynia się do zmiany warunków brzegowych naszej debaty. Paneuropejska dyskusja nad dochodem podstawowym lub emeryturą podstawową - które są też formą nowego spojrzenia na ekonomię - w sytuacji pracy, która staje się coraz częściej dobrem trudno dostępnym w warunkach nadchodzącej robotyzacji, ułatwia zmianę podejścia. Masowa utrata miejsc pracy, której obawia się i którą zapowiada w swoich raportach na temat celów milenijnych (SDG) ONZ sprawia, że stopniowo cała ekonomia "ludzka”, która ostanie się po falach postępującej robotyzacji będzie musiała w pewnym sensie stać się ekonomią społeczną.

Oddajemy zatem w ręce Czytelnika numer specjalny „Ekonomii Społecznej”, poświęcony szeroko rozumianemu wykluczeniu społecznemu. Wykluczenie społeczne ma wiele odcieni i jest złożone, tym samym wymaga dopasowanych przedsięwzięć i działań, które mogłyby je niwelować. Wykluczeniu bowiem można przeciwdziałać, wystarczy tylko mieć pomysł i chęć działania (szerzej: Lipowicz, 2013, s. 309). Pośród innowacyjnych rozwiązań, które można tutaj wskazać, zaliczyć należy niewątpliwie i te, które kształtują się na gruncie ekonomii społecznej; 
z natury swej stosującej kreatywne rozwiązania. Zróżnicowanie podmiotów ekonomii społecznej, pozwala na dopasowanie do swoistych potrzeb osób wykluczonych i dynamiki zmian zachodzących w ich otoczeniu.

Ekonomia społeczna jest przecież sferą życia społeczno-gospodarczego, która powstaje na pograniczu sektora przedsiębiorczości oraz sektora organizacji pozarządowych, niedziałających w celu maksymalizacji zysku. To sfera aktywności obywatelskiej i społecznej, która przez działalność gospodarczą i działalność pożytku publicznego służy: integracji zawodowej i społecznej osób zagrożonych marginalizacją społeczną, tworzeniu miejsc pracy, świadczeniu usług społecznych użyteczności publicznej (na rzecz interesu ogólnego) oraz rozwojowi lokalnemu (Uchwała nr 164 Rady Ministrów z dnia 12 sierpnia 2014 r. w sprawie przyjęcia programu pod nazwą „Krajowy Program Rozwoju Ekonomii Społecznej”). To właśnie podmioty ekonomii społecznej postrzegać powinno się jako stwarzające szanse powrotu na rynek pracy osobom z grup słabszych i marginalizowanych dzięki czemu mogą być one jednym z głównych dostarczycieli wielu usług społecznych (por.: Uchwała Rady Ministrów nr 165 z dnia 12 sierpnia 2014 r. w sprawie przyjęcia programu pod nazwą „Krajowy Program Przeciwdziałania Ubóstwu i Wykluczeniu Społecznemu 2020. Nowy wymiar aktywnej integracji"). A zatem wzrastający obszar wykluczenia społecznego to naturalna przestrzeń funkcjonowania podmiotów ekonomii społecznej. Wzmacnia ona bowiem zdolność do aktywizacji i reintegracji traktowanych podmiotowo jednostek, zagrożonych wykluczeniem. Dlatego jest to ekonomia potencjału i innowacyjnych koncepcji, poprzez szukanie nowych dróg dla rozwiązywania starych problemów. Poprzez włączanie w swoją strukturę i oparcie się na swoistych zasadach funkcjonowania, angażując w swe działania osoby zagrożone wykluczeniem - podmioty ekonomii społecznej inicjują proces włączenia społecznego, kreując pomosty przejścia z ekskluzji w inkluzję.

Spoglądając na dokonującą się aktualnie ewolucję w obszarze ekonomii społecznej, widoczne jest jej zredefiniowanie m.in. poprzez wyodrębnienie pojęcia ekonomii solidarnej, której celem jest w szczególności tworzenie miejsc pracy oraz reintegracja zawodowa i społeczna osób zagrożonych wykluczeniem społecznym, jak i rehabilitacja społeczna i zawodowa osób niepełnosprawnych. Wykluczenie społeczne jest zatem istotnym obszarem generowania form właściwych ekonomii społecznej, jak i kryterium pozwalającym na wyodrębnienie ekonomii solidarnej.

Ekonomia społeczna i solidarna to ekonomia wartości. Tych najistotniejszych i fundamentalnych. Godność osoby ludzkiej, solidarność, równość - najbardziej podstawowych, współkreujących aksjologicznie nasyconą przestrzeń ludzkich relacji w społeczeństwie. Społeczeństwo, które współtworzymy jest przecież społeczeństwem wartości. Dla nich się rozwijamy, walczymy, podejmujemy codzienny wysiłek rozwiązywania pojawiających się wyzwań. Jednym z nich jest niewątpliwie problematyka wykluczenia społecznego. Stosowne działania w tym względzie podejmują zarówno struktury administracji publicznej (rządowej, a zwłaszcza samorządowej), ale również - co szczególnie istotne w społeczeństwie obywatelskim - podmioty niepubliczne. Działania i jednych i drugich napędzane są dążeniem do przełamywania związanych z marginalizacją społeczną problemów. Podmioty ekonomii społecznej jednocześnie działalność swoją opierają na wartościach, a zarazem w ramach swej działalności wartości te rozwijają i urzeczywistniają.

Działania inkluzyjne to działania pozwalające na trwałe przywracanie poczucia godności, na odbudowywanie własnej podmiotowości poprzez włączanie w aktywne uczestniczenie w życiu społeczeństwa i współkreowanie jego struktur. „Utrata” przez społeczeństwo jednostek, które mogłyby pomnażać jego szeroko rozumiane zasoby, współtworzyć dobro wspólne, 
jest zjawiskiem niekorzystnym z perspektywy społeczeństwa jako całości, ale i oczywiście szczególnie z perspektywy jednostki, która doświadcza wykluczenia. Jakkolwiek nie próbowalibyśmy zdefiniować wykluczenia, uchwycić jego rozmaitych aspektów, czy też równie złożonych pojęć bliskoznacznych: izolacji, ubóstwa - są one niekorzystne dla jednostki, której dotykają. Przekładają się na jej trudną sytuację życiową z jaką musi się zmagać. Działania inkluzyjne podejmowane powinny być zatem na wszelkich szczeblach społecznego współegzystowania. I tu oczywiście pojawia się niezwykle istotna rola struktur administracji publicznej dla realizacji praw jednostki, struktur które powinny aktywnie wspierać takie osoby w tworzeniu systemowych rozwiązań pozwalających im na wychodzenie z ubóstwa czy też izolacji. Administrare to służenie, a w kontekście wykluczenia społecznego - to służenie godności człowieka. Administracja też może mieć swoją istotną rolę w inkubowaniu i rozwoju rozwiązań właściwych ekonomii społecznej, a te (spoglądając na codzienną, zaangażowaną działalność spółdzielni socjalnych, stowarzyszeń, fundacji, czy też i innych właściwych form) pozwalają godność urzeczywistniać, zamiast tylko deklarować.

Przeciwstawieniem wykluczenia społecznego jest ostatecznie solidarność społeczna. Wszystkie przedstawione opracowania ukazują różnorodne elementy, które mogą sprzyjać zasadniczemu zwiększeniu tej solidarności. Równocześnie dotykają one siłą rzeczy jedynie części bardzo szerokiego obrazu. W ostatnich latach dzięki postępowi badań dużo lepiej i głębiej rozumiemy istotę wykluczenia społecznego. Badania naukowe nie tylko w obszarze nauk prawnych wzbogaciły jego obraz obejmujący obecnie także np. ubóstwo energetyczne czy wykluczenie informacyjne, elementy poprzednio nie łączone bezpośrednio z kwestią wykluczenia. Do nowych elementów pokazujących, że kwestia przeciwdziałania wykluczeniu społecznemu pozostaje dynamiczna a postęp technologiczny otwiera stale nowe horyzonty, należy przykładowo kwestia komunikacji alternatywnej, która przeciwdziała wykluczeniu dużych kategorii społecznych osób, które nie mogą kontaktować się werbalnie, a dla ich potrzeb informacyjnych nie wystarcza język migowy ani alfabet Braille'a. Fakt, że pojawia się zupełnie nowa kategoria komunikacji i nowe instrumenty, łącznie z innowacyjnym, zintegrowanym systemem znaków, pozwalające znacząco poprawić sytuację tak zróżnicowanych kategorii osób jak osoby z autyzmem, pacjenci po udarze, czy chorzy na choroby neurodegeneracyjne, pokazuje nowe rodzaje i horyzonty niestandardowej pomocy społecznej, które powinny - tak jak w innych przypadkach - być obejmowane przez obowiązujące regulacje prawne. To ważny przykład tego, jak zmienia się rozumienie pomocy społecznej, jako nowej formy pomocy społeczeństwa dla osób obciążonych różnorodnymi ograniczeniami.

Państwo solidarności społecznej było wielkim marzeniem społecznego ruchu "Solidarność". Propagując jego zasady odwołujemy się zwykle do podstawowych wartości, do praw człowieka. Warto pamiętać również, że wyświadczone społecznie dobro wraca w postaci większej efektywności i mniejszych przyszłych wydatków budżetowych. Skoro zatem ekonomia społeczna wyrasta - w teorii i praktyce - w odpowiedzi na wielowarstwowy problem wykluczenia, w prezentowanych w ramach niniejszej monografii opracowaniach, wykluczenie zbadane zostało z rozmaitych - chcących je przybliżyć - perspektyw.

Dr hab. Piotr Szreniawski, prof. UMCS w swym tekście „Wykluczenie społeczne z perspektywy teorii rywalizacji hierarchii" metaforycznie zauważa, że wykluczenie w kontekście społecznym to pójście inną drogą niż ogół społeczeństwa. W swoich rozważaniach wykluczenie społeczne postrzega jako przykład pozbawiania jednostki członkostwa w zrzeszeniu bądź jako znaczne ograniczanie praw danej hierarchii. W tym kontekście życie społeczne postrzegane w danym kraju jest nie tylko jako rywalizacja mniejszych hierarchii, ale także jako przykład dzia- 
łania hierarchii, obejmującej całą sferę publiczną. Celem czynionych przez Autora rozważań jest wskazanie na możliwość stosowania teorii rywalizacji hierarchii do analizy zagadnienia wykluczenia społecznego, ukazanego w różnych kontekstach.

Natomiast dr Agata Barczewska-Dziobek - w tekście poświęconym prawnym formom współpracy jednostek samorządu terytorialnego z organizacjami pozarządowymi w zakresie przeciwdziałania wykluczeniu społecznemu - wskazuje, że wykluczenie społeczne uznawane jest za kategorię poznawczą, która pozwala analizować, opisywać oraz wyjaśniać sytuację grup defaworyzowanych. Istnienie nierówności i podziałów związane jest immanentnie z istnieniem społeczeństw, z tego też powodu wykluczenie społeczne stanowi przedmiot zainteresowania polityk publicznych skoncentrowanych na diagnozie i rozwiązywaniu problemów poszczególnych kategorii podmiotów wykluczonych. Wykluczenie społeczne, a konkretnie działania na rzecz przeciwdziałaniu bądź też minimalizacji skali tego zjawiska stanowi przedmiot działalności podmiotów pozarządowych. Samoorganizacja społeczeństwa jako przejaw solidaryzmu silniejszych z grupami wymagającymi wsparcia ma na celu wsparcie najbardziej potrzebujących w ramach działalności filantropijnej, charytatywno-opiekuńczej. Działalność państwa oraz organizacji pozarządowych w obszarze wykluczenia społecznego przebiegać może paralelnie, jednakże z punktu widzenia doniosłości tego problemu uzasadnione jest stworzenie podstaw współpracy w ramach przewidzianych prawem instrumentów.

Z kolei dr hab. Katarzyna Małysa-Sulińska, prof. UJ i mgr Anna Kawecka w kontekście problematyki wykluczenia, postanowiły zająć się wszechstronnie zasiłkiem celowym przyznanym w celu zaspokojenia niezbędnej potrzeby życiowej. Autorki słusznie zauważają, iż to właśnie w świetle regulacji naszej Konstytucji uzasadnione jest przyjmowanie w ustawodawstwie zwykłym ochrony nakierowanej na ochronę godności człowieka przed jego wykluczeniem społecznym. Polityka państwa realizowana w formie pomocy społecznej ma przeciwdziałać między innymi ubóstwu tak jednostki, jak i rodziny, a w związku z tym - związanemu z ubóstwem - wykluczeniu społecznemu. Wykluczenie zaś obejmuje wszystkie te przypadki, gdy dana osoba nie może - z uwagi nie na wewnętrzne przekonanie, ale czynniki znajdujące się poza jej kontrolą - uczestniczyć w określonym obszarze życia społecznego (np. gospodarczego, kulturowego, politycznego, zawodowego). Osadzając czynione rozważania na niniejszych założeniach autorki analizują zatem, czy zasiłek celowy jest świadczeniem stanowiącym skuteczne narzędzie przeciwdziałania wykluczeniu społecznemu.

Dr hab. Alina Miruć, prof. AEH zaprezentowała w swych analizach szczególną rolę wywiadu środowiskowego i pracownika socjalnego w procedurze przyznawania pomocy społecznej przy oparciu się na analizie obowiązującego prawa, wybranego orzecznictwa i poglądów doktryny. Nie ulega wątpliwości, iż rola wywiadu środowiskowego w sprawach z zakresu pomocy społecznej jest niezwykle istotna. Jest on bowiem sposobem zbierania informacji, rozmową z osobą starającą się o przyznanie świadczenia z pomocy społecznej (i jej rodziną), swoistym trybem postępowania dowodowego. Jako procesowy instrument winien zapobiegać trwałemu wykluczeniu społecznemu. Swoje rozważania Autorka poświęca również nowym regulacjom, które pojawiły się w związku z zagrożeniem COVID-19.

Dr Dorota Sylwestrzak gruntownie przeanalizowała problematykę aktywizacji osób starszych oraz przeciwdziałania ich wykluczeniu. Zasadniczym celem opracowania było przedstawienie rodzimych rozwiązań prawnych w tym obszarze. Zważywszy na rozległość niniejszych zagadnień rozważania ograniczono do realizacji zadań na poziomie gminy w zakresie wieloletniego programu "Senior+" na lata 2015-2020. Inicjatywę w zakresie aktywizacji osób starszych Autorka postrzega pozytywnie, gdyż w ten sposób realizowana jest funkcja opiekuńcza pań- 
stwa. Usytuowanie tych zadań na poziomie gminy uznaje za trafne z wielu powodów. Dzięki programowi "Senior+" gminy mogą uzyskać dodatkowe środki finansowe na realizację polityki senioralnej, w szczególności na stworzenie warunków do zwiększenia aktywnego i zdrowego trybu życia seniorów, udzielanie pomocy w czynnościach dnia codziennego, zapewnienie minimum jednego posiłku; w szczególności gorącego, czy też innych usług wspomagających, dostosowanych do potrzeb seniorów, jak również do integracji społeczności lokalnej, podnoszenie kompetencji i umiejętności seniorów. Ponadto z całą pewnością program ten sprzyja przeciwdziałaniu wykluczeniu osób starszych.

Przeciwdziałanie wykluczeniu społecznemu okazuje się najlepszą inwestycją na przyszłość. Zamiast osób żyjących latami z zasiłku zachowujemy czynnych członków społeczeństwa działających w „srebrnej gospodarce”, pracujących lub działających społecznie mimo ograniczeń, np. ciężkich przewlekłych chorób. W warunkach rosnącej przeciętnej wieku w Europie okazuje się to wręcz przyszłościową kwestią przetrwania Unii Europejskiej jako znaczącego podmiotu w zaostrzającym się globalnym współzawodnictwie gospodarczym. W miarę jak maleje znaczenie siły fizycznej przy wykonywaniu większości prac dzięki postępowi technologicznemu, poszerzają się kategorie osób uprzednio uznawanych za trwale niezdolnych do pracy, dla których praca ta staje się obecnie dostępna. Warto modyfikować więc polityki publiczne, programowanie gospodarcze oraz legislację w tym kierunku. Przedstawione opracowania stanowią wyraz takiego właśnie szerokiego podejścia, można wyrazić jedynie nadzieje, że ten kierunek badań będzie kontynuowany.

Wszystkim Autorom należą się słowa podziękowania za podjęcie tematów trudnych, ale jakże istotnych. Wszyscy wykazali bowiem głębokie zaangażowanie w niniejszy projekt.

Irena Lipowicz, Magdalena Małecka-Łyszczek

Redaktorzy

\section{Literatura}

Lipowicz, I. (2013). O mąre i wrażliwe państwo. Warszawa: Biuro Rzecznika Praw Obywatelskich.

Uchwała nr 164 Rady Ministrów z dnia 12 sierpnia 2014 r. w sprawie przyjęcia programu pod nazwą „Krajowy Program Rozwoju Ekonomii Społecznej", M. P. z 2014 r. poz. 811 z późn. zm.

Uchwała Rady Ministrów nr 165 z dnia 12 sierpnia 2014 r. w sprawie przyjęcia programu pod nazwą „Krajowy Program Przeciwdziałania Ubóstwu i Wykluczeniu Społecznemu 2020. Nowy wymiar aktywnej integracji”, M. P. z 2014 r. poz. 787.

\section{Informacje o autorach}

\section{Irena Lipowicz}

ORCID: 0000-0001-6794-6683

Katedra Prawa Administracyjnego i Samorządu

Terytorialnego

Wydział Prawa i Administracji

Uniwersytet Kardynała Stefana Wyszyńskiego

w Warszawie

ul. Wóycickiego 1/3, bud. 17

01-938 Warszawa

i.lipowicz@uksw.edu.pl
Magdalena Małecka-Łyszczek

ORCID: 0000-0002-8361-5064

Katedra Prawa Konstytucyjnego, Administracyjnego ¡ Zamówień Publicznych

Instytut Prawa

Uniwersytet Ekonomiczny w Krakowie

ul. Rakowicka 27, 31-510 Kraków

maleckam@uek.krakow.pl 


\section{Prawa autorskie i licencja / Copyright and License}

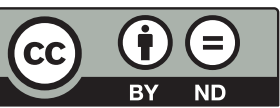

Publikacja na licencji Creative Commons Uznanie autorstwa Użycie niekomercyjne - Bez utworów zależnych 4.0 Międzynarodowe (CC BY-ND 4.0) http://creativecommons.org/licenses/by-nc-nd/4.0/deed/pl

This work is published under the terms of the Creative Commons Attribution - NoDerivetives International (CC BY-ND 4.0) License http://creativecommons.org/licenses/by-nc-nd/4.0

Wydane przez Uniwersytet Ekonomiczny w Krakowie. Małopolska Szkoła Administracji Publicznej

Published by Cracow University of Economics - Krakow, Poland. Małopolska School of Public Administration of the Cracow University of Economics 